\title{
Ealing's Colour Aesthetic: Saraband for Dead Lovers
}

\author{
Keith Johnston
}

When Ealing's first Technicolor film, Saraband for Dead Lovers (1948), was released in 1948, critics were divided over its merits both as a colour film and an Ealing production. In a summary of critical reviews of the film that appeared in The Cinema Studio, the Daily Worker claimed it had 'seldom seen Technicolor used to such superb effect', while the Daily Express regarded the Technicolor as 'subdued' and 'gloomy'. The Daily Herald described the colour photography as 'pictorially, a lesson to Hollywood', yet the Daily Mail listed it as 'lurid and ferocious'. Dilys Powell, in The Sunday Times, summed up both sides by noting that earlier audiences might have been excited 'by the audacity of the colour-designing' but these days they were unlikely to be 'dazzled by it' (C.A.W. 1948b: 16). Ealing Studios' aesthetic approach was also questioned. The Evening Standard stated the combination of topic and budget had 'overwhelmed' the small studio, the Evening News noted that 'the film leans towards the theatrical' in place of the 'preferred ... more realistic treatment', and many reviews mirrored the Daily Graphic's commentary on spectacle overshadowing human character and narrative: 'The film is rich in everything but emotional quality' (C.A.W. 1948b: 16). In the years since its release, Saraband for Dead Lovers has continued to stand in opposition to the traditional view of Ealing's black-and-white documentary-realist tradition. A period drama with lush, extravagant costumes and sets, the film is a melodramatic narrative of love and forbidden sexuality in seventeenth-century Hanover, filmed in striking Technicolor. To explore how this potent use of colour cinematography challenged the Ealing aesthetic, this essay will combine historical analysis of the film's production history and contemporary critical reception with textual analysis of how colour was used to create and add meaning to character and narrative events. Applying this synthesis to Saraband 


\section{Keith Johnston}

for Dead Lovers reveals why colour remains a potent, though untapped, approach to the history of this famous studio. ${ }^{1}$

Ealing's move into colour film-making appears to be at odds with its alleged preference for 'realism and restraint' (MacNab 1993: 96) and the studio's association with the 1940s critical tradition of the 'quality film adventure' (Ellis 1996). Characterising British cinema as restrained, realistic and true-to-life, 'the films of Ealing Studios... [were seen] as the foremost examples of this trend' particularly when compared to the 'sensational and visually flamboyant' melodramas produced by Gainsborough (Chapman 2005: 37). ${ }^{2}$ Yet in the postwar years, Ealing was one of several production companies encouraged to move into colour production by their financial backer, the Rank Organisation, which believed that bigger budget colour films could succeed internationally (Barr 1980: 188). In 1947 and 1948 some key British Technicolor films were released, including Black Narcissus (1947), Blanche Fury (1947), An Ideal Husband (1947), Jassy (1947) and The Red Shoes (1948). Two distinct cinematographic styles have been identified in this moment of transition: Blanche Fury features a low-key, high-contrast aesthetic that uses Technicolor to 'reflect the emotional content of the scene' (Petrie 1996: 99), while Jassy uses highkey lighting in order to 'show off the lavish sets, designed by Maurice Carter, and Elizabeth Haffenden's brightly coloured ballgowns' (Petrie 1997: 132). For its first attempt at adding colour to the established studio aesthetic, Ealing would borrow elements from both Blanche Fury and Jassy but push beyond what either film had yet accomplished.

The production of Saraband for Dead Lovers was already problematic without the addition of colour photography. Frank Miller has claimed Rank ordered Ealing to adapt Helen Simpson's popular fact-based romance novel (Miller 2008), while Michael Balcon always maintained that the adaptation of Saraband was his idea, part of a larger project to widen Ealing's scope beyond documentary realism. In a promotional article for the film, Balcon insisted that 'over-insistence on realism' could adversely affect Ealing (and the British film industry). He noted that if studios relied 'on camera work faking the effect of actuality filming... if the employment of amateur actors is done not for reasons of necessity... but, again, for an artificial effect of realism... then what is to happen to the film as an art form?' (Balcon 1948: 11). His solution was to apply Ealing's production knowledge and documentary expertise to new genres: "it will be interesting to see the work of technicians trained in the new realistic approach to contemporary film-making, tackling the historical romantic film' (Balcon 1948: 11). Director Basil Dearden supported Balcon's version of events, stating that the studio head was determined to push the envelope of what 
Ealing was capable of producing, 'planning a subject more ambitious than any the studio had attempted' (Dearden 1948: 65). Saraband for Dead Lovers can, therefore, be seen in this light: the desire to expand the artistic and aesthetic boundaries of Ealing's films and avoid the 'formation flying' of contemporary British productions. Although not a commercial success, Saraband represented a potential new direction for Ealing Studios and established a place for colour film-making within Ealing's production schedule for the next decade.

Designed as a film that would move beyond Ealing's traditional filmmaking boundaries, the Technicolor aesthetic of Saraband for Dead Lovers was problematic for the studio's publicity department. The film's pressbook notes that the production team decided 'that the safe road of economy of colour was not the right one for this story', using colour 'to enhance the mood and characters' (Saraband for Dead Lovers pressbook 1948). This seems to back up Balcon's suggestion that realism was no longer the sole thrust of Ealing productions, and that the studio was willing to experiment into new arenas. Yet the same pressbook stresses the 'pains' of 'historical research and attention to detail' which 'lends realistic colour to the authentic historical background of the film'. The film's production designer, Michael Relph, also stated that the film was an attempt to 'get away from the Gainsborough-type costume picture, which was totally unreal, and to do a serious historical epic' (Relph, quoted in Vallance 2004). This discourse suggests the film was pulled in two directions: the traditional Ealing reliance on realism and accuracy, and the 'unsafe' and expressive aesthetic road offered by colour. Ultimately, the film exists in both worlds. It presents detailed and accurate sets and dramatises events from history, but it also allows colour composition to act as a symbolic force within the narrative.

Like most Ealing films, Saraband for Dead Lovers can be seen as a group effort. But alongside Balcon, Dearden, Relph, screenwriter Alexander Mackendrick and costume designer Anthony Mendleson, the film's dominant aesthetic voice seems to have been provided by cinematographer Douglas Slocombe. ${ }^{3}$ Constantly pushing against the restrictions imposed by Technicolor, the film stands as a practical demonstration of Slocombe's theories on colour photography and the use of black space:

Technicolor were fairly insistent that one should light fairly flatly... there should be a minimum exposure, certainly in shadow areas and on the whole there should be a fairly low contrast ratio... I found that this was most unexciting... the most exciting thing on the Technicolor screen was black ... deep shadows and things ... I went out of my way to do that kind of thing. (Slocombe 1996: tape 1, side 2) 


\section{Keith Johnston}

The sharp delineation between strong colour and the black shadowy areas of the frame provide some of the film's more lasting images. Slocombe's approach to lighting and framing Technicolor must also be seen in relation to his dismissal of the American approach. He described the composition of many US Technicolor films as a 'child's kaleidoscope shaken up to the tune of a tango' that causes the eye to 'wander all over the screen, vainly trying to settle somewhere' (Slocombe 1948: 87). Like other British cinematographers (notably Jack Cardiff and Guy Green), Slocombe preferred to use colour to guide the eye, subtly offering clues that enhance both character psychology and narrative information. ${ }^{4}$

Slocombe's colour credo was not "whether the hues are true to life but whether pleasing and dramatic use has been made of them' (Slocombe 1948: 85). This is clear from the opening credits and initial images, which foreground key colours - red and blue-as well as emphasising Slocombe's low-key lighting style. The credits feature six themed title slides, listing title, names of cast and crew, and then introductory narrative information. The lettering is contained within a scarlet red area that makes up the bulk of the screen. Surrounding this red area is a series of ornate drawn borders, resembling golden picture frames or grand mirror surrounds. The red area, containing the white writing, draws the eye initially, but the frames themselves merit further investigation. In the opening image, above 'An Ealing Studios Production', the carved frame features a red-coated figure on horseback, two cherubs with long-stemmed horns, and wide golden wings that spread out to the left and right of frame. The ornate, lush quality of these images foreground the baroque and romantic setting of the film, but they also relate to the words within the red space: the horns trumpeting the arrival of a new film, the figure on horseback leading a new charge for Ealing (into colour film-making), a studio which is literally spreading its wings with this production (see Figure 1).

This series of title slides contain basic narrative, or thematic, references: martial images of swords and flaming torches relate to the European wars of the seventeenth-century setting, drawings of royal crests and figures focus on the regal elements of the story, while a darkening screen of skeletons and skulls atop a pile of spears and swords foreshadows the shadowy, gothic nature of the narrative. When the film cuts to its first live action image, the frame darkens even further, to a blue-grey landscape surrounding the grey, shadowy castle of Ahlden, with a single light in its tower. After the brilliance of the red in the titles, the descent into darker, more ominous colours 


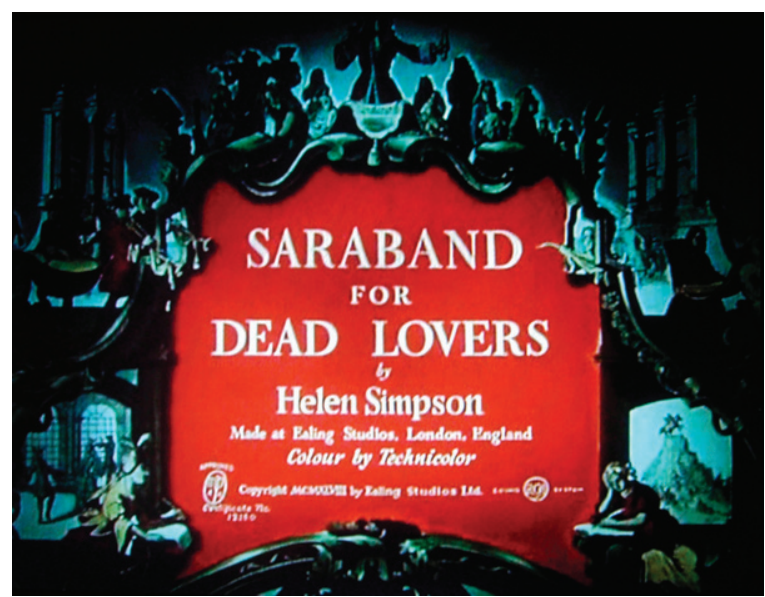

Fig. 1. Colour arrives at Ealing Studios: title, Saraband for Dead Lovers.

is striking-particularly the faded blue light that washes over the landscape-a move from the 'richness' of the titles to the 'the grey colouring of death' (Relph 1948: 79). This deathly blue-grey effect continues as the film cuts to the rooftops of Hanover, panning across striking diagonal lines of raked roofs and towers. A thin shard of blue light cuts across the shadows as the camera peers down into a narrow street. The strong use of low-key lighting here, delineating the black shapes of the buildings through highlights of cold blue light, gives these opening scenes an unsettling Expressionist quality. They also confirm Slocombe's belief in the Technicolor black. The shadows, and the chill blue-grey light that reveals skewed aspects of the city, set a tone for Hanover that the film will develop through set design (the royal box at the theatre) and costume (guard uniforms and royal outfits). The recurring blue images link Hanover back to the deathly isolation of these first scenes.

From the cold world of Hanover's political and royal machinations, the film offers a pointed comparison with a cross-fade to the beautiful sunny location of Celle. Here there are tall trees, wide lakes, white castles and natural colours. The film cuts to a long shot in a forest, as a young Sophie-Dorothea (Joan Greenwood) bounds into frame. In a flowing yellow dress with bright red hair and framed against the natural green of the trees, she offers a positive, colourful figure. This depiction of Celle and Sophie-Dorothea was planned to be 'gay, sunny, and pervaded by a joyful carefree atmosphere' (Slocombe 1948: 87), where 'everything is light and sunshine' (Relph 1948: 80). This 


\section{Keith Johnston}

portrayal continues inside the castle, where Sophie-Dorothea's mother, sister and father are equally colourfully dressed. Here, the shots start as high contrast, more similar to Jassy in tone, emphasising the costume design and the scale of the castle's interior. However, a darker presence begins to creep into this bright atmosphere, as Sophie-Dorothea sees Hanover's elderly Electress (Françoise Rosay) lurking in the corner, enclosed within a deep green (almost black) cape. As she rises from this position, the Electress spreads into the frame, a dark cancer in the pastel pretty world of Celle. The colour scheme darkens as she further dominates the family, pressing a dark emerald-green ring into Sophie-Dorothea's hands, branding her with the darker colour scheme of her Hanoverian family. In this opening sequence, colour has defined location, character and narrative event. The naive primary colours of Sophie-Dorothea's world are disrupted and altered by the darker tones of Hanover, symbolising the contrast between these two spaces and the move towards unhappiness and death.

Once in Hanover, Sophie-Dorothea is forced to conform to her new family and role as wife and mother. While the costumes of other members of court, particularly her husband George Louis (Peter Bull) and Countess Platen (Flora Robson), become more pronounced and colourful, Sophie-Dorothea wears simple dresses of white and pink. As she becomes more attracted to the Swedish prince Konigsmark (Stewart Granger), she visibly retreats into the blue-tinged Hanoverian colours. When she first rejects his advances by stating 'So, we should be like them, snatching at pleasures?' she refers to Hanover as 'them' while herself wearing a light blue dress that matches the earlier Hanoverian hues. Indeed, this assumption of the Hanover colour takes on a symbolic role in the film's set piece, the Hanover Fair. Here, as Sophie-Dorothea struggles through the crowded streets, the camera passes stalls that are selling dolls of her and George Louis: the image of her in a blue dress has become enshrined as her official celebrity image in the streets of Hanover.

The Hanover Fair sequence was widely discussed by those who worked on Saraband for Dead Lovers and the critics who reviewed the film. This status as a central pivot within the film is partly because of its use of bold colours to represent the chaos of the Fair, but mainly because the colour aesthetic is used to suggest character psychology and state of mind. The Fair was intended to create a 'nightmarish effect ... packed with as many and varied colours as possible ... [a] violent clash and conflict' (Relph 1948: 83-4). The film's pressbook counters this with reference to the Fair as adding 'realistic colour to the authentic historical background of the film'-another instance where 


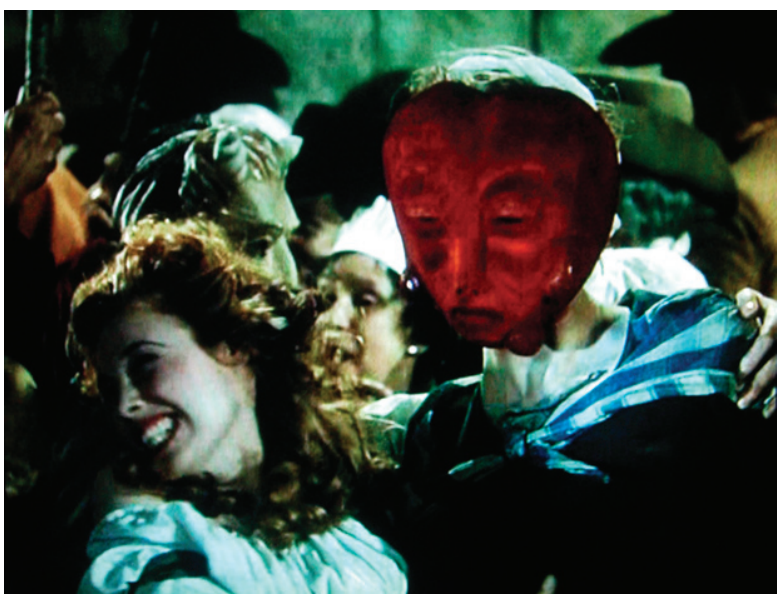

Fig. 2. Hanover Fair as colour spectacle.

the film's dual identity of Ealing and visual spectacle was pulling it in different directions. Here, the level of research and the deployment of colour are tied to authenticity, falling back on Ealing's tradition of realism. Yet the construction of the sequence is in stark contrast to the rest of the film and any claims of realism: a sharply edited barrage of faces, masked figures and colourful fairground crowds through which Sophie-Dorothea struggles. Strong colours and strange faces thrust into camera: red masks, silver horses' heads, purple and gold capes, animal masks, revellers in green and yellow. Ealing's research department may have found historic sources for these costumes, but the presentation is less about realism than colourful spectacle and montage (Figure 2).

At the start of the scene, Sophie-Dorothea is closed off, desiring isolation from the Fair outside. Her room is bathed in a blue light, with deep black shadows that recall the initial introduction of Hanover's streets at night. Echoing that earlier sense of uncertainty and doom, and reasserting Hanover's colour scheme (and control over SophieDorothea), the sequence is more concerned with her internal mood and emotions. Cocooned in her room, the life and dangerous vitality of the Hanover Fair threatens to intrude, a constant yellow glow of torchlight that pulses beyond the wooden shutters of her window. When these shutters blow open, letting in the noise and light from outside, there is an immediate change in Sophie-Dorothea's manner as she snatches up the gold mask that lies on her bed. The film cuts to her pushing through the explosion of colour outside. Overwhelmed, 


\section{Keith Johnston}

she shies away from knife throwers whose red-handed blades spin through the air towards a blue board, fire-breathers whose mouths blaze red-orange, people in red and blue demon-masks (the colours most associated with her husband), and the passing swirl and pulse of green, yellow, red and purple costumes. The film visually represents the chaos within Sophie-Dorothea's mind in this wild, unruly fair, and she is pulled into the centre of this colourful world.

Audience access to character psychology in this sequence is intrinsically tied to the film's use of Technicolor. Unlike the kaleidoscope of Technicolor that Slocombe derided in American films, the collision of colours here (particularly after the more pastel tones used elsewhere) function as a dramatic narrative and character cue. One of the stated intentions of the film was that colour should 'boldly enhance ... mood and character' (Saraband for Dead Lovers pressbook 1948) and here, as Sophie-Dorothea collapses against the door to Konigsmark's apartment, the use of colour reaches its pitch. As she swoons against the door, the crowd surge forward to help her. In the long shot, Sophie-Dorothea is surrounded by a whirl of colour. Then the film cuts to a close image of four gloved hands banging on the door. These gloves - in striking blue, red and yellow-become a potent image that the film returns to four times in this moment, cutting between them and Sophie-Dorothea's confused, frightened face. By giving herself over to emotion, by accepting her desire for Konigsmark, she has embraced the chaos and colour of the Fair: and that colourful gaiety now helps her to gain access to Konigsmark. But allowing herself to experience this life has overwhelmed her. The Fair, and its colours, are too much for her, and she pushes away from them, back into the streets and straight into the arms of Konigsmark. He carries her away into his house: and away from the strong colours of the Fair. Within his room, Sophie-Dorothea can recover her senses: his house is cast in a more faded hue, while he is dressed simply in black and white.

The overall tone of the Hanover Fair sequence fits with Slocombe's insistence that by lighting darker, he was able to direct 'the observer's eye ... to the focal point' of the scene (Slocombe 1948: 87). In this case, it is the white-costumed Sophie-Dorothea and the bright colours of the Fair that surround, and engulf, her. The explosion of colour in the Hanover Square sequence was designed as a highpoint of the film, and identified as such in Ealing's promotional materials. In narrative terms, it builds to the consummation of the love affair between Sophie-Dorothea and Konigsmark, but it also suggests how colour, while providing an obvious spectacle, can add to audience awareness 
of characterisation and increase identification. One of Ealing's most impressive sequences, this bravura example of editing, colour design and framing presents a wordless succession of images that recalls silent cinema in its ability to convey narrative and character information without the reliance on dialogue. Colour aids this process through carefully expanding the scope of what's being shown, offering the shock elements of grotesque masks and the strident carnival sideshows, but also the more subtle elements of the torchlight that bathes proceedings or the coloured gloves that come to Sophie-Dorothea's aid.

Colour and silence are also central to the final swordfight in the royal palace. Alerted by Countess Platen that Konigsmark is attempting to leave the country with Sophie-Dorothea, the Hanoverian royal guard set a trap for him. Entering the hall on the upper level, Konigsmark senses something is wrong. The colour scheme has already established this for the audience, having returned to the blue-grey lighting seen in the opening images and the deep shadows that characterised those first shots of Hanover. The night exteriors of the city have now entered the royal palace, and Slocombe's use of Technicolor black and lowkey lighting increase the narrative tension as a game of cat-and-mouse ensues. This sequence runs over three minutes with no additional lighting or colour: the blue light that is cast on some surfaces is almost swallowed by the shadows as Konigsmark stalks the soldiers. The cinematography only reveals glimpses of furniture, swords, statues and faces, enveloping the audience in the same atmosphere of death and foreboding. Although this moment ends as a covered lantern is dropped and flame red light reveals more aspects of the location, it stands (like the opening scenes and the Hanover Fair) as a bold experiment in colour photography. Expanding the existing Ealing aesthetic into new symbolic areas, these photographic options allowed character, narrative events and psychology to be conveyed through colour alone.

Having pushed the colour aesthetic in filming, promotional materials focused on Technicolor as a key sales message. Exhibitors were told that campaigns 'should be based on star values plus Technicolor photography!' while the pressbook highlighted innovations in Technicolor developed by Ealing and Rank, with specific reports on how British cosmetic firm Leichner had created 'Kamera-Klear' make-up that was unaffected by the higher set temperatures caused by Technicolor lighting requirements (Saraband for Dead Lovers pressbook 1948). The articles emphasised how this make-up accentuated Joan Greenwood's natural skin colour and 


\section{Keith Johnston}

offered full colour showcards of Greenwood for promotional purposes. Yet there remains an uncertainty over how to position Ealing in relation to colour film more generally. Posters state it is Ealing's 'first Technicolor film', but they focus much more on star and narrative conventions than technology. Equally, while the pressbook refers to the Hanover Fair sequence and to how colour enhances mood and character, it also falls back on star profiles and historical background. Stressing the film's use of bold colour choices was not necessarily in vogue with contemporary critical opinion on how British films should look or what subjects they should address. As shown in the critical response, reviews of Saraband for Dead Lovers were mixed, suggesting that while pageantry, political intrigue and Stewart Granger were decent box-office attractions, the film might be 'too puzzling for normal audiences' (Daily Herald, in C.A.W. 1948b: 16).

Ealing's experiment with Saraband for Dead Lovers, to augment its established realist style with a more flamboyant Technicolor palette, to expand beyond contemporary narratives with a rich and romantic period piece, did not lead to an immediate revolution within the studio aesthetic. The reasons for this were largely commercial: the colour film cost almost $£ 300,000$ to make and was not a financial success, either at home or abroad. Given that the average Ealing budget was around $£ 80,000$, the experiment did little to encourage future investment in expressive colour film-making or period melodramas. Their second Technicolor film, Scott of the Antarctic (1948), premiered six months after Saraband, but the promotional tone focused more on Britain's heroic past and the problems of filming in realistically snowy conditions. Colour was not central in pressbook articles or promotional materials, referred to as a useful tool to convey the reality of desolate icy landscapes rather than an expressive device in its own right. Unlike the possibilities explored in their first colour film, Scott of the Antarctic stayed on the safe road of economy of colour. Despite this, Ealing did not give up on colour film-making and it remained a key element to the studio's production schedule through the 1950s. Between 1948 and 1957 the studio produced 46 films, thirteen of which were in colour. Yet despite making up a quarter of its output, the Ealing colour aesthetic is unexplored territory, an element of mise-en-scène that has received little commentary or analysis.

Duncan Petrie states that none of Douglas Slocombe's subsequent Ealing colour films 'matched the bold richness of his debut' (Petrie 1996: 139). While it may be true that the signature low-key shadows and bursts of bright colour that characterise Saraband for Dead Lovers are not as prevalent in later pictures, they remain key aesthetic 


\section{Ealing's Colour Aesthetic}

devices. The Rainbow Jacket (1954) features low-key effects in both a photographic lab sequence and a final scene where the disgraced jockey hangs up his outfit for the last time. Out of the Clouds (1956) builds tension during a dangerous airplane landing by highlighting specific areas of its darkened control room set in lurid red and green hues. The Ladykillers (1955) pushes towards a similar expressionist style in several places, most notably its low-key introduction of the Professor (Alec Guinness) or any of the scenes featuring the fateful railway bridge. The films also use strong primary colours to reveal narrative or character traits. When The Titfield Thunderbolt (1953) replaces its black train with a gleaming red, green and gold engine, the train's victory over the insipid cream coach service is guaranteed. Equally, The Ladykillers is replete with red imagery: from the bright modernity of telephone boxes and the inherent danger of train signals to the redhued walls of the room where the gang hide the stolen money.

These films were not all photographed by Slocombe, but it seems likely that his experience on Saraband for Dead Lovers influenced the other Ealing cinematographers Paul Beeson, Otto Heller and Geoffrey Unsworth. Throughout the 1950s, the Ealing colour films continued to stick to Slocombe's theory that colour should be used for 'pleasing and dramatic' use, and that 'light and shade' should have a specific purpose within the narrative. Although other British cinematographers shared similar beliefs, Slocombe publicised his theories on colour film-making through articles and interviews in relation to Saraband and his other Ealing films. This means that while there is no set colour palette or dominant aesthetic within the Ealing colour films, the influence of Slocombe and his work on the first colour production was never far away.

Saraband for Dead Lovers has never received the critical attention of Ealing's other productions, possibly never recovering from Charles Barr's description of it as 'an expensive, ponderous and loss-making period spectacle' (Barr 1980: 188). Yet the film stands as a striking example of the expansion and potential that Ealing Studios was capable of in the late 1940s, and contains a strong and impressive colour aesthetic that informed many later Ealing films. Analysis of the historical and textual content of Saraband for Dead Lovers demonstrates that Ealing was not simply the cosy, whimsical studio of legend, but a vital force for change within the British film industry. Instead of quietly fulfilling their part in the quality film adventure, collaborative film-makers like Balcon, Dearden and Slocombe were pushing to see what new technology could offer the studio (and the wider industry) and willing to test the aesthetic boundaries in the process. In the years 


\section{Keith Johnston}

following Saraband, Ealing would continue to work with Technicolor, but would also expand to use EastmanColor (Lease of Life, Out of the Clouds, The Feminine Touch), and Technicolor's own widescreen process, Technirama (Davy). Far from a backwards-looking slice of old England, the studio's attempts to keep pace with developments in international film technologies represent an unknown fragment of the Ealing myth. Perhaps it is time to broaden the horizon of Ealing scholarship beyond the canon of comedy and social realism into the fields of colour, to move beyond black-and-white realism to explore Ealing's Technicolor fantasies.

\section{Notes}

1. Ealing's colour films are Saraband for Dead Lovers, Scott of the Antarctic (1948), Where No Vultures Fly (1951), The Titfield Thunderbolt (1953), The Love Lottery (1954), West of Zanzibar (1954), The Rainbow Jacket (1954), Lease of Life (1954), Out of the Clouds (1955), Touch and Go (1955), The Ladykillers (1955), The Feminine Touch (1956) and Davy (1957).

2. Charles Barr also traces the forging of 'a distinctive Ealing identity and style' (Barr 1980: 40), while Duncan Petrie describes the films as sharing 'a broadly naturalistic aesthetic' (Petrie 1996: 34). For a fuller discussion on the Ealing documentary aesthetic, see either Barr (1980) or Ellis (1975).

3. Douglas Slocombe was one of Ealing's most prolific cinematographers, working on some of the studio's most iconic films: Dead of Night (1945), Hue and Cry (1947), It Always Rains on Sundays (1947), Kind Hearts and Coronets (1949), The Lavender Hill Mob (1951), The Man in the White Suit (1951) and Mandy (1952). He worked on five other Ealing colour films: The Titfield Thunderbolt, The Love Lottery, Lease of Life, Touch and $G o$ and Davy.

4. For more on other British cinematographers of this time period and their attitude towards Technicolor, see Petrie (1996).

\section{References}

Balcon, M. (1948), 'The eye behind the camera', in Saraband for Dead Lovers: The Film and Its Production at Ealing Studios, London: Convoy Publications, pp. 9-11.

Barr, C. (1980), Ealing Studios, Woodstock, NY: Overlook Press.

C.A.W. (1948a), 'Saraband for Dead Lovers review', The Cinema, 71: 5699, pp. 9-10.

C.A.W. (1948b), 'Culling the Critics discussing-Saraband for Dead Lovers', The Cinema Studio, 1: 25, p. 16

Chapman, J. (2005), “The true business of the British movie”? A Matter of Life and Death and British film culture', Screen, 46: 1, pp. 33-49.

Dearden, B. (1948), 'Organised inspiration', in Saraband for Dead Lovers: The Film and Its Production at Ealing Studios, London: Convoy Publications, pp. 65-7.

Ellis, J. (1975), 'Made in Ealing', Screen, 16: 1, pp. 78-127.

Ellis, J. (1996), 'The quality film adventure: British critics and the cinema 1942-948', in A. Higson (ed.), Dissolving Views: Key Writings on British Cinema, London: Cassell, pp. 66-93.

MacNab, G. (1993), J. Arthur Rank and the British Film Industry, London: Routledge. 
Miller, F. (2008), 'Saraband for Dead Lovers', Turner Classic Movies website, http://www.tcm.com/thismonth/article/?cid=12654\&rss=mrqu (accessed 15 April 2008).

Petrie, D. (1996), The British Cinematographer, London: BFI.

Petrie, D. (1997), 'Innovation and economy: the contribution of the Gainsborough cinematographer', in P. Cook (ed.), Gainsborough Pictures, London: Cassell, pp. $118-35$.

Relph, M. (1948), 'Designing a colour film', in Saraband for Dead Lovers: The Film and Its Production at Ealing Studios, London: Convoy Publications, pp. 76-84.

Saraband for Dead Lovers pressbook, BFI microfiche.

Slocombe, D. (1948), 'Colour through the camera', in Saraband for Dead Lovers: The Film and Its Production at Ealing Studios, London: Convoy Publications, pp. 85-7.

Slocombe, D. (1996), BECTU Oral History Project, 68.

Vallance, T. (2004), 'Michael Relph obituary', The Independent, 2 October, http:// www.independent.co.uk/news/obituaries/michael-relph-550637.html (accessed 15 April 2008).

Keith Johnston is a Lecturer in Film and Television Studies at the University of East Anglia.

DOI: $10.3366 / \mathrm{E} 1743452109001319$ 